\title{
The Role of Low Dose Misoprostol in Cervical Ripening and Induction of Labour Beyond the Age of Viability and its Effects on Maternal and Fetal Outcomes
}

\author{
Humaira Ali, M.D., ${ }^{1}$ Cimona Lyn Saldanha, M.S., ${ }^{2}$ Tabasum Parveiz, M.D.,, Rabia Khurshid, M.D. ${ }^{2}$
}

\author{
'Senior Resident, Department of Obstetrics \& Gynecology, SKIMS, Srinagar \\ ${ }^{2}$ Associate Professor, Department of Obstetrics \& Gynecology, SKIMS, Srinagar \\ ${ }^{3}$ Professor Department of Obstetrics \& Gynecology, SKIMS, Srinagar
}

\section{A B S T R A C T}

This study was conducted to compare the efficacy and safety of oral $(50 \mu \mathrm{g})$ and vaginal $(25 \mu \mathrm{g})$ misoprostol for cervical ripening and induction of labour. Two hundred patients with indications for labour induction randomly received either $50 \mu \mathrm{g}$ oral misoprostol every $4 \mathrm{~h}$ (Group-l) or $25 \mu \mathrm{g}$ vaginal misoprostol every $4 \mathrm{~h}$ (Group-II), for maximum of six doses. Mean induction to delivery time, delivery within 24 hrs, mode of delivery, oxytocin use, number of doses used, failed induction rate and maternal complication and fetal outcomes were compared for the two groups. Mean induction delivery time was significantly longer in Group-I ( $20.55 \pm 5.59 \mathrm{hrs})$ than in Group-II ( $16.70 \pm 7.12 \mathrm{hrs})$ (with mean difference of 3.85 and $P$-value of $<0.001$ ). Mean number of doses of misoprostol used for oral and vaginal misoprostol study populations were $2.61 \pm 0.94$ and2.37 \pm 1.20 respectively. Oxytocin augmentation was required in significantly more number of patients in oral group $(80 \%)$ than in vaginal group ( $68 \%$ ) with P-value of 0.027 . There were 3 failed inductions in the oral and 4 in the vaginal group after a total of six doses of misoprostol. Incidence of maternal and fetal complications was similar between two groups. Our findings indicated that, $25 \mu \mathrm{g}$ vaginal misoprostol has the potential to induce labor as safely as, and more effectively than, $50 \mu \mathrm{g}$ oral analogue. JMS 2017; 20(1):18-21

\section{INTRODUCTION}

Induction implies stimulation of contraction before spontaneous onset of labour. The primary condition that must be fulfilled to interfere with this natural process is that terminating pregnancy would benefit the mother and/or fetus. Since ages various methods for induction have been used. Prostaglandins (PGs) are nowadays often used for induction of labour. Expression of myometrial prostaglandin receptors increases in late gestation ${ }^{1}$. $\mathrm{PGE}^{2}$ analog dinoprostone is currently the only prostaglandin approved by United States Food and Drug Administration (US FDA) for cervical ripening and induction of labour. Disadvantages of dinoprostone are that it is expensive, requires strict refrigeration and cannot be used in patients with ruptured membranes.

There is a need for less costly and less temperature

\section{Correspondence}

Dr. Cimona Lyn Saldanha

Consultant, Post graduate Dept. of Obstetrics \&

Gynecology, SKIMS, Srinagar- 190010 J\&K State

e-mail: clyns@rediffmail.com sensitive alternatives. PGE1 analog misoprostol is the upcoming alternative. Use of prostaglandins followed by intravenous oxytocin is generally accepted to be the standard induction method for women with unfavorable cervix ${ }^{2,3}$.

Advantages of misoprostol over dinoprostone are that it is not expensive, is easily stored, can be administered by more than one route and can be used in ruptured membranes. Several studies attest to efficacy of $\mathrm{PGE}^{1}$ analog misoprostol in comparison to $\mathrm{PGE}^{2}$ analog dinoprostone ${ }^{4,5}$. WHO endorses the role of misoprostol by including it in WHO model list for essential medicines6.

For induction of labour misoprostol is mainly used by oral and vaginal routes. The ideal dose, route, and frequency of administration of misoprostol are still under investigation. There are several reports describing orally administered misoprostol for induction of labour ${ }^{7-9}$. Bennett et al found that orally administered misoprostol induced labour as effectively as vaginally administered misoprostol; however, the time interval from administration to vaginal 
birth was longer in orally administered group ${ }^{9}$. Advantage of oral administration of misoprostol is the ease of administration and its noninvasiveness. Orally $50 \quad 100 \mu \mathrm{g}$ have been used in various studies ${ }^{10-12}$.

Vaginal administration has advantages of decreasing systemic side-effects with profound effect on reproductive tract; also the bio-availability of vaginally administered misoprostol is more than twice that of orally administered misoprostol ${ }^{13}$. Time interval to delivery is decreased and a lower dose of drug is needed. Vaginally $25 \mu \mathrm{g}$ or $50 \mu \mathrm{g}$ misoprostol are used. The most common vaginal dose used has been $50 \mu \mathrm{g}$ misoprostol, inserted once or administered every four to six hours. Inserting $25 \mu \mathrm{g}$ misoprostol every six hours intra-vaginally has been associated with the fewest side effects ${ }^{14,15}$.

\section{METHODS}

This study was conducted over a period of $2 \mathrm{yrs}$ (Sep. 2012-Aug. 2014) in the Post graduate department of Obstetrics and Gynecology, Sher-i-Kashmir Institute of Medical Sciences, Srinagar, Kashmir.

Pregnant women beyond the gestational age of viability, with a medical or obstetrical indication for induction of labour, were evaluated for participation in this study. Subjects with singleton pregnancy, longitudinal lie, cephalic presentation, reactive fetal heart rate, maternal age of 20-35 yrs, estimated fetal weight of more than $2 \mathrm{~kg}$ and less than $4 \mathrm{~kg}$ and parity of less than 3 were included. Exclusion criteria included patients in active labour, multiple pregnancy, malpresentation, estimated fetal weight $\geq 4 \mathrm{~kg}$ or $<2 \mathrm{~kg}$, evidence of cephalo-pelvic disproportion, placenta previa or any other contraindication to vaginal delivery, history of uterine incision, evidence of chorioamnionitis, parity of more than three, signs and symptoms of fetal distress, herpes simplex (active) and contraindication to use of prostaglandins.

After admitting the patient, fully informed consent was taken. Detailed history was taken and a complete clinical examination was done. Cardiotocography and sonography was done in all patients. Subjects were randomly assigned to two groups (1:1). In one group $25 \mu \mathrm{g}$ of misoprostol was put in posterior fornix of vagina, and in other $50 \mu \mathrm{g}(25 \mu \mathrm{g}$ two tablets) of misoprostol was given orally. Dose was repeated every four hours to a maximum of $150 \mu \mathrm{g}$ (6 doses) in vaginal group and to a maximum of
$300 \mu \mathrm{g}$ ( 6 doses) for those who did not get adequate uterine contractions ( 3 in $10 \mathrm{~min}$ ). Strict monitoring of fetal heart and uterine contractions was done.

Primary outcomes assessed were in terms of vaginal delivery within $24 \mathrm{hrs}$, induction to delivery time, change in Bishop's score and neonatal outcome. Secondary outcomes assessed included caesarean delivery, oxytocin use for augmentation, number of doses required, hyper stimulation syndrome, passage of meconium and tachysystole.

Induction was considered successful when delivery occurred within $24 \mathrm{hrs}$ of induction. Augmentation with oxytocin was done when uterine contraction frequency was fewer than 2 in 10 minutes, failure to progress in active phase of labour (less than $1 \mathrm{~cm}$ in $1 \mathrm{hr}$ ), after adequate cervical ripening (dilatation of $\geq 3 \mathrm{~cm}$ or Bishops of $\geq 8$ ) and failure to enter labour after maximum doses.

\section{RESULTS}

Two hundred women were enrolled for participation in this study, out of whom 198 were taken for final analysis as two women withdrew. These subjects were randomly assigned into two groups: Group-I included 98 women who were administered $50 \mu \mathrm{g}$ of oral misoprostol 4 hourly to a maximum of 6 doses and Group-II included 100 women who were administered $25 \mu \mathrm{g}$ of vaginal misoprostol 4 hourly to a maximum of 6 doses. The demographic characteristics and indications for induction of labour are shown in Table 1. The groups were similar in mean maternal age, gestational age, gravidity distribution, pre-induction Bishop's score and indication for induction (PIH and post-datism accounting for 59\% patients in group I and $50 \%$ patients in group II).

Table 1:

\begin{tabular}{|c|c|c|c|}
\hline Variable & $\begin{array}{c}\text { Group I } \\
\text { Oral Misoprostol } \\
\text { Mean } \pm \text { SD }\end{array}$ & $\begin{array}{c}\text { Group II } \\
\text { Vaginal Misoprostol Mean } \pm \text { SD }\end{array}$ & P-value \\
\cline { 3 - 4 } Age (yrs) & $28.07 \pm 2.36$ & $27.62 \pm 2.50$ & 0.194 \\
\hline Gestational Age (weeks) & $39.23 \pm 1.40$ & $39.15 \pm 1.26$ & 0.660 \\
\hline Gravidity n (\%) & $70(71.4)$ & $66(66)$ & \multirow{2}{*}{0.410} \\
Primigravida & $28(28.57)$ & $34(34)$ & \\
Multigravida & & & \\
\hline Indication for induction & $32(32.65)$ & $27(27)$ & \\
PIH & $26(26.54)$ & $23(23)$ & \multirow{2}{*}{0.857} \\
Postdatism & $18(18.36)$ & $24(24)$ & \\
PROM* & $14(14.28)$ & $18(18)$ & \\
Oligohydramnios & $6(6.12)$ & $6(6)$ & \\
Rh-ve & & & \\
\hline
\end{tabular}

${ }^{*}$ Premature Rupture of Membranes 
Mean induction delivery time (Graph 1) was significantly higher in Group-I than in Group-II. There was no difference in terms of delivery within $24 \mathrm{hrs}$, mode of delivery, incidence of maternal complications, neonatal complications and failed induction between the two groups (Table 2).

\section{Graph 1}

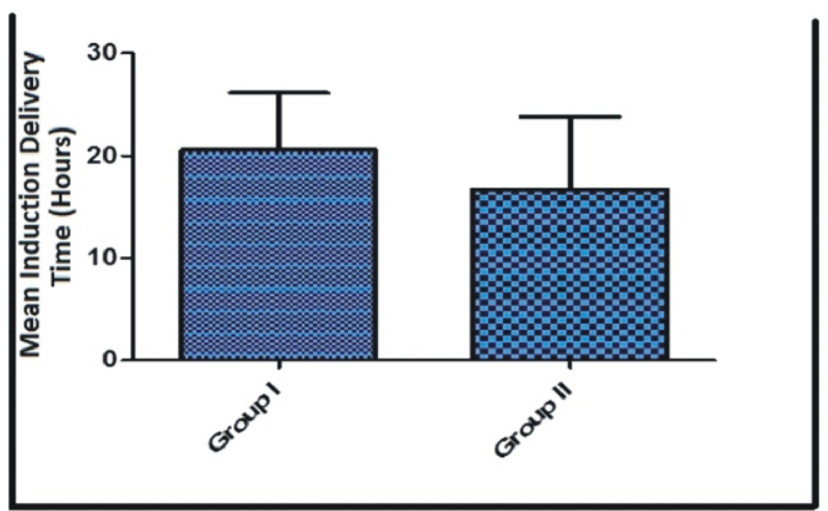

There was no difference in terms of mode of delivery; $18 \%$ in both groups were delivered by LSCS, $2 \%$ in Group-I and 5\% in Group-II had instrumental delivery. In terms of neonatal outcome both the groups had similar results; NICU admission and APGAR score were similar in two groups. There was no difference in incidence of meconium stained liquor.

Mean number of doses required were slightly higher in Group-I than in Group-II. But this difference was statistically insignificant. $81.63 \%$ of patients in Group-I and $68 \%$ in Group-II required oxytocin augmentation. This difference is statistically significant (Table 2 ).

\section{Table 2:}

\begin{tabular}{|c|c|c|c|}
\hline Variable & $\begin{array}{l}\text { Group I } \\
\text { Oral Misoprostol } \\
\text { Mean } \pm S D\end{array}$ & $\begin{array}{c}\text { Group II } \\
\text { Vaginal Misoprostol Mean } \pm S D\end{array}$ & P-value \\
\hline Delivery Induction Time (Mean \pm SD) & $20.55 \pm 5.59$ & $16.70 \pm 7.12$ & $<0.001^{*}$ \\
\hline $\begin{array}{c}\text { Induction delivery time } \\
<24 \\
>24\end{array}$ & $\begin{array}{l}63(64.29) \\
35(35.71)\end{array}$ & $\begin{array}{l}72(72) \\
28(28)\end{array}$ & 0.244 \\
\hline $\begin{array}{l}\text { Oxytocin Augmentation } \\
\text { No } \\
\text { Yes }\end{array}$ & $\begin{array}{l}18(18.36) \\
80(81.63)\end{array}$ & $\begin{array}{l}32(32) \\
68(68)\end{array}$ & 0.027 \\
\hline $\begin{array}{l}\text { NICU Admission } \\
\text { No } \\
\text { Yes } \\
\end{array}$ & $\begin{array}{l}88(89.80) \\
10(10.20)\end{array}$ & $\begin{array}{c}92(92) \\
8(8) \\
\end{array}$ & 0.590 \\
\hline $\begin{array}{c}\text { Maternal complications Tachysystole } \\
\text { Hypertonus } \\
\text { Hyper stimulation } \\
\text { Nausea/Vomiting } \\
\text { Diarrhea } \\
\text { Postpartum hemorrhage }\end{array}$ & $\begin{array}{c}2(2.04) \\
0 \\
0 \\
5(5.10) \\
4(4.08) \\
2(2.04)\end{array}$ & $\begin{array}{c}4(4) \\
0 \\
2(2) \\
2(2) \\
1(1) \\
2(2)\end{array}$ & 0.625 \\
\hline
\end{tabular}

\section{DISCUSSION}

Misoprostol is an efficacious agent for labour induction. Compared with dinoprostone nearly every measure of adequacy of labour induction was superior with misoprostol including induction to delivery time, lack of necessity of oxytocin, fewer doses, and delivery within 24 hours. ${ }^{3,6}$ Various studies attest to efficacy of PGE1 analog misoprostol in comparison to PGE2 analog dinoprostone ${ }^{2}$. Our results showed that $25 \mu \mathrm{g}$ vaginal misoprostol was more effective than $50 \mu \mathrm{g}$ oral misoprostol for cervical ripening and induction of labour as mean induction to delivery time was lower in vaginal group. Similar results were seen in study conducted by Wing et $\mathrm{al}^{16}$ and Shetty et $\mathrm{al}^{17}$, although doses used by Shetty et al were $50 \mu \mathrm{g}$ vaginally. There was no difference in terms of delivery within $24 \mathrm{hrs}$ between two groups and number of vaginal deliveries within $24 \mathrm{hrs}$. Similar results were seen in a study done by Rahman et $\mathrm{al}^{18}$.

Number of doses required in two groups were similar. There was no difference in mode of delivery. Neonatal outcome both the groups had similar results; NICU admission and APGAR score were similar in two groups. There was no difference in incidence of meconium stained liquor. These results were similar in a study done by Rahman et $\mathrm{al}^{18}$. In a study conducted by Kwon et $\mathrm{al}^{19}$ median doses required were higher in oral group (1-8) than in vaginal group (1-3) but doses used by them were $50 \mu \mathrm{g} 6$ hourly vaginally and orally.

In our study $81 \%$ patients in Group-I and $68 \%$ in Group-II required oxytocin augmentation. This difference is statistically significant. Similar to our results, Wing et al reported that Oxytocin administration was necessary in $75 \%$ and $59 \%$ of their patients who received oral and vaginal misoprostol respectively ${ }_{16}$. This difference was statistically significant. Uterine tachysystole developed in $2 \%$ and $4 \%$ of the women in Group-I and Group-II respectively. Hyper stimulation occurred in 3\% patients in Group-II and none in Group-I. Nausea and/or vomiting occurred in $5.1 \%$ and $2.0 \%$ of patients in Group-I and Group-II respectively; diarrhea was reported by $4 \%$ and $2 \%$ of patients respectively. PPH (postpartum hemorrhage) occurred in $2 \%$ patients in each group. There was no statistically significant difference in incidence of maternal complications between two groups. Similar results were seen in a study done by Wing et $\mathrm{al}^{16}$. 


\section{CONCLUSION}

Our study concluded that vaginal misoprostol $25 \mu \mathrm{g} 4$ hourly is more effective than, and as safe as, oral misoprostol 50 $\mathrm{g}$ $4 \mathrm{hrly}$ for cervical ripening and induction of labour.

Larger studies are required to find out the least effective dose and the most favourable route for misoprostol in induction of labour.

\section{REFERENCES:}

1. Brodt-Eppley J, Myatt L. Expression of contractile FP and relaxatory EP2 receptor in human myometrium during gestation and labour. J Soc Gynaecol Invest 1998;5(suppl.):133.

2. RCOG clinical effectiveness support unit. Induction of labour Evidence based guidelines vol-9: RCOG Press; 2001.

3. American college of obstetricians and gynaecologistsvol 10. Washington DC: ACOG 1999

4. Wing DA, Rahall A, Jones MM. Comparison of misoprostol and prostaglandin E2 gel for preinduction cervical ripening and labour induction.Am $\mathrm{J}$ of obstetgynaecol 1995;172:1804-10.

5. Wing DA, Ortiz G, Paul RH. Comparison of intermittent administration of misoprostol with continuous dinoprostone for cervical ripening and labour induction.Am J ObstetGynecol 1997; 177:61218.

1. World Health Organization. WHO Model List of Essential Medicines. 17th ed. Available at http://whqlibdoc.int/hq/2011/a95 053-eng.pdf. [Published 2011].

2. Toppozada MK, Anwar MYM, Hassan LA, et al. Oral or vaginal misoprostol for induction of labour. Int $\mathrm{J}$ Gynaecolobstet 1997;56:135-9.

3. Windrim $\mathrm{R}$, Benett $\mathrm{K}$, Mundle $\mathrm{W}$, et al. Oral administration of misoprostol for labour induction: a randomised controlled trial. ObstetGynecol 1997;89:392-7.
4. Bennett KA, Butt K, Crane JMG, et al. A masked randomised comparison of oral and vaginal administration of misoprostol for labour induction. ObstetGynecol 1998;92:481-6.

5. Hall R, Duarte-Garde M, Harlass S. oral vs vaginal misoprostol for labour induction. ObstetGynecol 2002;99:1044-8.

6. Wing DA, Park MR, Paul RH. Randomised controlled trial of oral vs vaginal misoprostol for labour induction. ObstetGynecol 2000;95:905-8.

7. Crane JMG, Delaney T, Hutchens D. Oral misoprostol for premature rupture of membranes at term. Am J Obstet Gynecol 2003; 189:720-724

8. Zieman M, Fong SK, Benowitz NL, et al. Absorption kinetics of misoprostol with oral or vaginal administration. Obstet Gynaecol 1997;90:80-92.

9. Cheng S, Ming H, Lee J. Titrated Oral Compared with Vaginal Misoprostol for labor Induction. A Randomized Controlled Trial. Obstet Gynecol 2008;111:119-25.

10. Wing DA, Paul RH. Misoprostol for cervical ripening and labour induction: the clinicians prespective and guide to success. Contemp Ob Gyn 1999;44:46-61.

11. Wing DA, Hamm D, Paul RH. Comparason of orally administered misoprostol with vaginally administered misoprostol for cervical ripening and labour induction. Am J Obstet Gynecol 1999; 180:1155-60.

12. Shetty A, Danielian P, Templeton A. A comparison of oral and vaginal misoprostol tablets in induction of labour at term. BJOG 2001;108(3):238-43.

13. Rahman H, Pradhan A, Kharka L, et al. Comparative evaluation of 50 microgram oral misoprostol and 25 microgram intravaginal misoprostol for induction of labour at term: a randomized trial. J Obstet Gynaecol Can. 2013;35(5):408-16.

14. Kwon JS, Davies GAL, Mackenzie VP. A comparison of oral and vaginal misoprostol for induction of labour at term: a randomised trial. BJOG 2001;108:23-26. 